\title{
Local Perception of Climate Change and Adaptation in Mangrove Areas of the Cameroon Coast
}

\author{
Ndongo Din 1,2*, Vanessa Maxemilie Ngo-Massou ${ }^{1,3}$, Guillaume Léopold Essomè-Koum ${ }^{1,2}$, \\ Ernest Kottè-Mapoko', Jean Michel Emane', Akusa Dorice Akongnwi' ${ }^{2}$, Richelieu Tchoffo ${ }^{1}$ \\ ${ }^{1}$ Department of Botany, Faculty of Science, The University of Douala, Douala, Cameroon \\ ${ }^{2}$ Technical Assistance Unit, Environmental and Social Management Plan of the Mefou Watershed, Cameroon \\ Water Utilities Corporation Project, Douala, Cameroon \\ ${ }^{3}$ Department of Biological Sciences, High Teacher's Training College, The University of Yaounde I, Yaounde, \\ Cameroon \\ Email: "ndongodin@yahoo.com
}

Received 8 March 2016; accepted 24 May 2016; published 27 May 2016

Copyright (C) 2016 by authors and Scientific Research Publishing Inc.

This work is licensed under the Creative Commons Attribution International License (CC BY).

http://creativecommons.org/licenses/by/4.0/

(c) (i) Open Access

\begin{abstract}
Mangroves supply essential ecosystem services to tropical informal economies. In the Cameroon coastal region, the impacts of various projections on change in temperatures and precipitations sound low compared to the pressure of human activities. This survey evaluated the sensitivity of local population on the impact of climate change and the vulnerability of coastal ecosystems. An investigation carried out on 425 individuals was based on the major income and development activities, the knowledge of the subject, the information sources, the origin of changes, perceptible effects, risks and consequences. More than $90 \%$ of interviewees have heard about climate change essentially from radio $(20 \%)$. Industries $(47.53 \%)$ are perceived to have major responsibility for temperature $(78 \%)$ and precipitation $(67 \%)$ changes and increased inundation $(39.07 \%)$ was perceived as the highest risk. Compared with Cartesian predictions in the area, the results have shown the sensitivity of population to local variation of climate factors. No efficient endogenous measure has been recorded. Forest and specially mangroves are the most affected ecosystems by local activities. Expected extension of the dry season could affect the natural regeneration and the structure of mangrove forests. Considering the importance of woody species in the local economies, the lack of appropriate actions and adaptation measures will lead to the total degradation of mangroves.
\end{abstract}

\section{Keywords}

Anthropogenic Activities, Investigation, Prediction, Risks, Vulnerability

\footnotetext{
"Corresponding author.
}

How to cite this paper: Din, N., Ngo-Massou, V.M., Essomè-Koum, G.L., Kottè-Mapoko, E., Emane, J.M., Akongnwi, A.D. and Tchoffo, R. (2016) Local Perception of Climate Change and Adaptation in Mangrove Areas of the Cameroon Coast. Journal of Water Resource and Protection, 8, 608-618. http://dx.doi.org/10.4236/jwarp.2016.85050 


\section{Introduction}

Several studies indicate that climate change is already taking place, and that the climate system is likely to experience some amount of change, regardless of whether emission reductions are successfully undertaken [1] [2]. The regional, seasonal, and diurnal character of projected future warming is still a matter of considerable debate, but nearly all scientists agree that future decades will be marked by a warming due to anthropogenic activities [3]. Atmospheric composition, particularly an increase of concentration of long-lived greenhouse gas is significantly altered by human activities. This means that each country must carefully assess how it may be affected by climate change and how adaptations might be made. For the Intergovernmental Panel on Climate Change (IPCC), adaptation is "the process of adjustment to actual or expected climate and its effects" [4]. So, these national assessments are particularly important for countries that are vulnerable to current climate variability, environmental stresses, and growing socioeconomic pressures.

The fast increase in the gas issue rate for purpose of greenhouse, since the industrial revolution of the 19th century, has led to a constant increase of their concentration in the atmosphere, with serious potential consequences on the climate of our planet. The possible future modifications of the climate on a regional or local scale must be evaluated as of now, according to the precautionary principle. However this taking into account cannot be effective and requires that one has the clearest possible vision of disturbances. That requires estimating the climatic emissions, and future concentrations and modifications which would result from it.

As in certain areas of Africa, Cameroon is characterized by a strong climatic variation since 1960 . The rise of pluviometry is palpable on annual, seasonal and monthly scales. The issue here is to bring out an analysis of the evolution of the climate parameters in Cameroon since 1961 to 2000 in order to establish the bond between the climatic disturbances and their impacts in certain development sectors such as agriculture, fishing, water and energy, etc. Significant studies on variability and the climatic fluctuations in relation to the development and the environment showed rainfall deficits of about $20 \%$. These values might be sometimes higher than $25 \%$ on the Atlantic coast and in the forest areas that confirms that "wet" Tropical Africa is regularly under the effect of climatic variability [5].

Mangroves in Africa cover over 3.2 million ha, corresponding to about 20\% of its global coastline coverage, with approximately 1.5 million ha located along the Atlantic coast [6]. As a consequence of the enormous anthropogenic pressures and multiple threats, a decline of more than $25 \%$ of the West African mangroves has been observed over the past 25 years [7]. In West Africa, Cameroon harbours approximately $2000 \mathrm{~km}^{2}$ land area of mangroves, distributed along the coast of the Guinean gulf [8]. Almost 53,216 ha of the Cameroon's mangrove forests have been lost over the last 13 years [9].

Rapid population growth has affected resources, including arable land, food supplies, water and energy, especially in developing countries where government policy-makers still pay little attention to protect these coastal ecosystems [10] [11]. It is projected that anthropogenic climate change is likely to have adverse impacts on African ecosystems and their biodiversity, but projections of impacts based on a range of methodologies diverge widely [12]. These differences relate to the extent to atmospheric $\mathrm{CO}_{2}$ and disturbance on ecosystem structure and productivity, and relative strengths in accounting for temperature-versus water-related controls on biodiversity. In Cameroon, human activities appear to be the main factor influencing the structure and dynamic of mangroves. Mangrove deforestation is occurring at a rate of $1 \%-2 \%$ per year, which implies that most forests will disappear within this century [13]. These disturbances in mangroves have been attributed to a combination of such factors due to the absence of adequate legislation regarding mangrove protection, and pollution in the peri-urban settings [14].

In spite of their biological, economic and ecological values, mangroves continue to be greatly degraded because of sea level rise [15] [16], herbivore pressure [17] [18] and ever increasing anthropogenic disturbances [19]-[23]. In the modern evidence, local variability plays a key role in predicting whether or not mangroves of a specific region will survive [24]. Their survival is due to a variety of key features and multiple feedbacks which serve to either facilitate or augment recovery from, or resilience to, natural and anthropogenic disturbances [25]. The IPCC defines three types of adaptation: anticipatory, planned and autonomous [26]. To date, attention has primarily focused on adaptation undertaken to autonomous by local populations. So, the aim of this survey is to evaluate the sensitivity of local population to the impact of climate change and vulnerability of coastal ecosystems. 


\section{Material and Methods}

\subsection{Study Site}

Cameroon is located on the Gulf of Guinea in Central Africa. It lies between latitude $1^{\circ} 40^{\prime} \mathrm{N}$ and $13^{\circ} 05^{\prime} \mathrm{N}$ and between longitude $8^{\circ} 30^{\prime} \mathrm{E}$ and $16^{\circ} 10^{\prime} \mathrm{E}$. With a surface area of $475,412 \mathrm{~km}^{2}$, it has an extremely diversified landscape, including a variety of climatic and geomorphologic zones. The four major ecological zones of Cameroon include a tropical forest zone, a coastal and maritime zone, a savannah zone and a sudano-sahelian zone. Mangroves area cover about $1961.84 \mathrm{~km}^{2}$ grouped into three blocks [9]. The study was carried out in a coastal zone between Limbe and Kribi (Figure 1) where mangrove stands are dominated by Rhizophora spp. The area is dominated by two types of climate. In the north and center part, the climate belongs to a particular equatorial regime called Cameroonian regime, characterized by a long rainy season (March-November) and a short dry season (December-February) with annual average temperature of about $26.7^{\circ} \mathrm{C}$ [22]. In the south (Kribi), the climate is of a typical equatorial regime with four seasons (two rainy seasons and two dry seasons well individualized), marked by high and stable temperatures of about $28.7^{\circ} \mathrm{C}$. The climate is influenced by the trade winds of both hemispheres, depending on season and location: the Harmattan and the Atlantic monsoon winds.

Heavy annual rainfall totals are observed from more than $5000 \mathrm{~mm}$ in the Limbe area and decreased to about $3000 \mathrm{~mm}$ in the Kribi area. During the spring tide, the tidal regime reaches $3 \mathrm{~m}$ in the Cameroon Estuary, $1.2 \mathrm{~m}$ in the mouth of Nyong and $1.5 \mathrm{~m}$ in Kribi [27]. The annual variation in salinity ranges between $0 \%$ and $20 \%$. The relative humidity is always close to the saturation rate. Soils are grey or black muds, of silty, sandy or clay texture, and deriving from fluvial sediments. The content of organic matter is relatively low, $1 \%$ to $3 \%$ with carbon: nitrogen ratio (C:N) often lower than 10 in the whole area.

The flora consists essentially of tree species. The herbaceous stratum represents $<1 \%$ of the entire vegetation. However, the flora remains poor with Rhizophora racemosa GF Meyer being largely the dominant vegetation in all sites. The faunal component includes vertebrates, such as birds, reptiles and fishes, and a wide range of invertebrates, mainly crabs and molluscs which constitute the bulk of benthic diversity in the region [28] [29].

\subsection{Data Collection}

Local perception of climate change and adaptations were assessed using a wide range of methodologies. The methodology of evaluation used two generally known methods. A participative process based on specific investigations with the populations, to express their perception of the phenomenon associated with an analysis with the data of the climatic parameters.

The participatory process data were generated by conducting semi-structured interviews with local residents (living in the immediate vicinity of the mangroves) and our field based observations. The results of the investigations have been supplemented by the traditional methods used in the evaluation of the mangroves risks and the vulnerability to the climatic changes [30]. The questionnaire is of mixed type or semi-structured with the choice of short answers suggested on one hand, and on the other, free answers where each questioned person will be able to provide his/her opinion without being influenced, with the advantage of widening the opinions in the analysis of the results [22].

Interviews were conducted in French, English and local languages, sometimes with the help of translators. The households were sampled opportunistically (i.e., interviewing people in their homes as well as those out of their homes). To avoid recurrent information, only one person ( $>20$ years of age) per house was questioned. The preference was given to (local) elderly people who have been living in the site for more than a generation and therefore could relate changes that had occurred in adjacent mangroves to certain events or conditions. Interviewees were asked if the surrounding mangrove forest coverage had increased, decreased or remained unchanged. Likewise, an attempt was made to distinguish whether local informants perceived mangrove forests as less or more degraded over time. They were urged to provide the causes of the reported changes and the derived consequences on their livelihood. They were also asked questions about any observed changes in the mangrove ecosystem.

\section{Results and Discussions}

\subsection{Local Perception of Climate Change}

A total of 425 persons were questioned. More than $55 \%$ of interviewees have heard about climate change essentially 


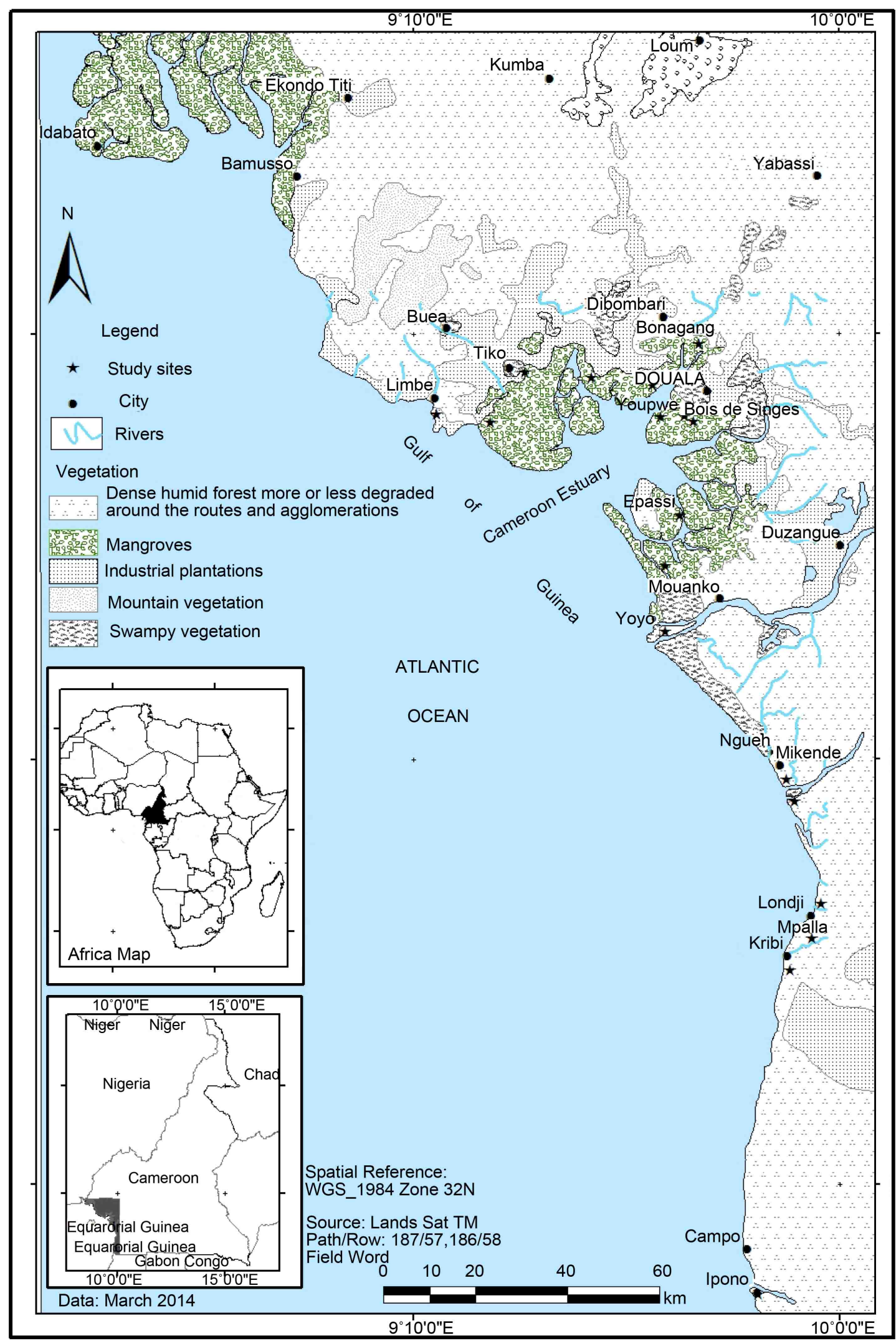

Figure 1. Distribution of mangrove ecosystems in the Cameroon coastal atlantic front [31]. 
from radio (20\%), followed by television (17.7\%) and newspapers (15\%). The effects of the climatic changes felt are the rise of the temperatures (78\%) and the rise of precipitations (67\%). These effects have been felt for more than 10 years (72.7\%). Contrary to scientific predictions, populations observed an increase of precipitations accompanied with the rise of floods frequency. Temperature increases are likely to result on faster growth, reproduction, photosynthesis and respiration, changes in community composition, diversity and an expansion of latitudinal limits [32]. In the tropical and subtropical areas, as these changes are occurring, mangrove expansion also be coupled to changes in precipitation [33].

The most practiced activities are trade of wood (24.5\%), fishing (20.5\%) and agriculture (19\%). The degree of land utilization exploitable is raised and profits from the favorable climatic conditions. Industries through gas emissions, followed by transport and deforestation are responsible of the changes according to the interviewees (Figure 2). The production of charcoal and firewood constitutes the most significant form of woody species exploitation. The firewood thus constitutes the principal fuel in the households and the techniques of cutting down do not respect any rules. Moreover, this activity is the single cause denounced by the populations. The abuse of the vegetable biofuels takes place mainly by the forest and/or agro-industrial development companies. The coastal zone represents the major economic pole of the country and the increases of development activities are accompanied with the emissions of GHG which deteriorate the atmosphere layer and modify the climate characteristics. The loss of natural $\mathrm{CO}_{2}$ sinks and reservoirs results in about $12 \%-20 \%$ of anthropogenic greenhouse gas emissions [34].

The major risks of the climate change according to the interviewees are inundation, soil erosion and salt water intrusion (Figure 3). Increased inundation and erosion are the two main mechanisms by which land can be lost as a result of sea level rise. The risks of accelerated sea-level rise with climate change are further enhanced by

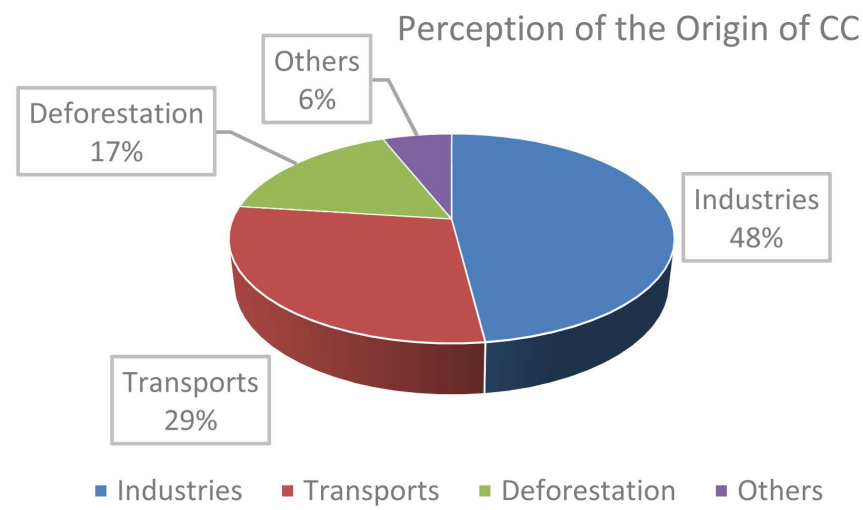

Figure 2. Perception of the origin of climate change in the coastal area of Cameroon.

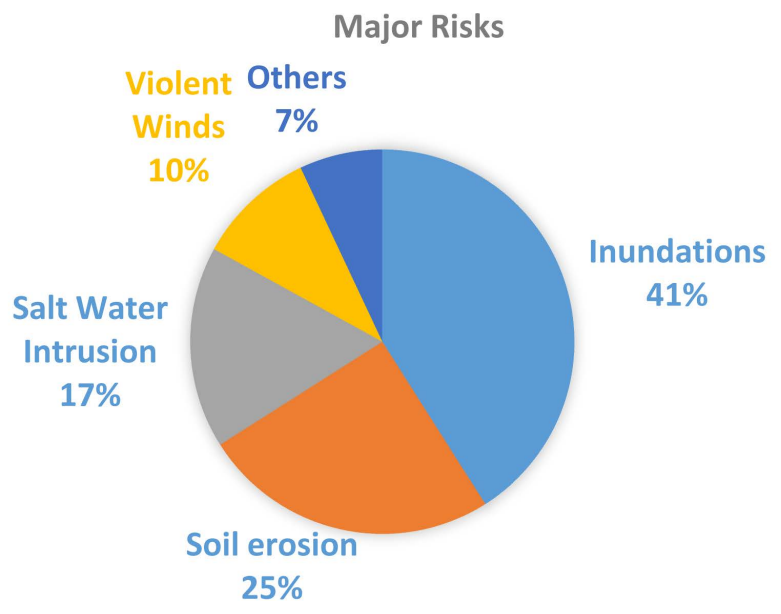

Figure 3. Assessment of major risks due to climate change. 
associated increases in frequency of extreme sea level, waves and the storm surges, resulting in higher intensity and frequency of flooding and erosion of vulnerable coastal areas [35] [36]. Observed and anticipated future rates of sea-level rise are likely to have far-reaching impacts on mangrove forests, raising concerns that such wetlands are vulnerable to drowning and coastal squeeze [37]. Mangroves can respond individually or collectively to sea level rise. Species-specific tolerances to prolonged water logging such as flooding resistance, differences in morphology and anatomy in relation to environmental change are being observed [38] [39].

In Cameroon estuary, the effects of inundation will be more important than erosion, since the zone is largely dominated by muddy coasts. Consequently, the few sandy beaches in the mangrove area could be destroyed (Figure 4). Increased erosion could also result in the removal of mangrove soils that lie above mean sea level, with subsequent deposition offshore [40]. Erosion along the seaward margin of the mangrove would also expose less productive anaerobic soils, leading to a better-oxidized and more productive soil system. At regional scales of many low-lying delta environments, geological processes and exacerbated anthropogenic activities such as groundwater extraction augment the relative sea level rate [41] [42].

As the trees recede, more rapid erosion would occur, resulting in the formation of small cliffs in the seaward front. The salinity of mangrove creeks is relatively low, but varies with time and location. It has been reported that salinity on the same day varied between $17.5 \%$ and $19.5 \%$ at Mabeta, and between $12 \%$ and $17.5 \%$ at Tiko [43]. The phenomenon of salt water intrusion occurs in all of the rivers of the Cameroon estuary, including the Wouri, the Mungo and the Dibamba. The predictions of changes will worsen the potable water supply in the dry season, especially in the Douala city which is the biggest town of the country and where two of the three upper watersheds are used for water catchment.

Intense human development within mangrove ecosystems, coupled with the rapid urbanization of adjacent towns and the excessive utilization of trees for the production of firewood, charcoal, and clearing for agricultural purposes, has led to the gradual degradation of these ecosystems. This degradation is expected to become worse in the future, largely as a result of a climate change that would induce sea level rise and salt water intrusion.

\subsection{Perception by Gender}

Only, $17.8 \%$ of women noted that the climate of their area has changed against $82.2 \%$ of men. The most widespread channel of information is radio (women, $35.6 \%$ and men, $41.6 \%$ ). This change has been felt since 5 years for $69.3 \%$ of women, and since 10 years for $52.3 \%$ of men. The ages of the individuals were gathered into three classes of amplitude 20 with a base of 20 years. The first class was the most represented, while the class of 60 80 years was the least (Figure 5(a)). Nearly $62 \%$ of individuals of the first class, $27.5 \%$ of the second class and $10.5 \%$ for the third were informed of the climatic changes (Figure 5(b)).

The channel of information more used is television for the young people, the press for the medium (40 - 60 years) and the radio for the old people (Figure 6(a)). This change would have occurred since nearly 5 years for the young people, 10 years for the people between 40 - 60 years and more than 15 years for the old people (Figure 6(b)).

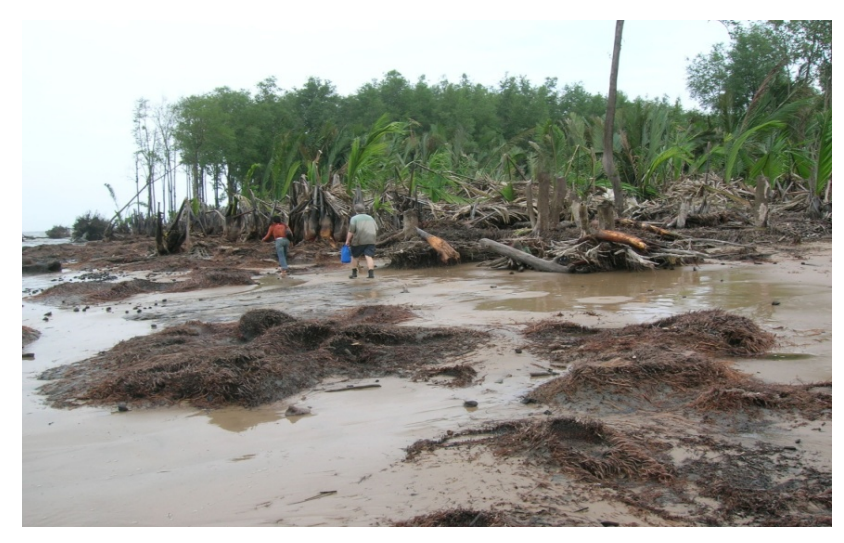

Figure 4. Coastal erosion demonstration in mangrove area near Bakassi: stumps of Nypa fruticans followed by a pile of dead trunks of Rhizophora racemosa in front of a small Avicennia germinans forest stand. 


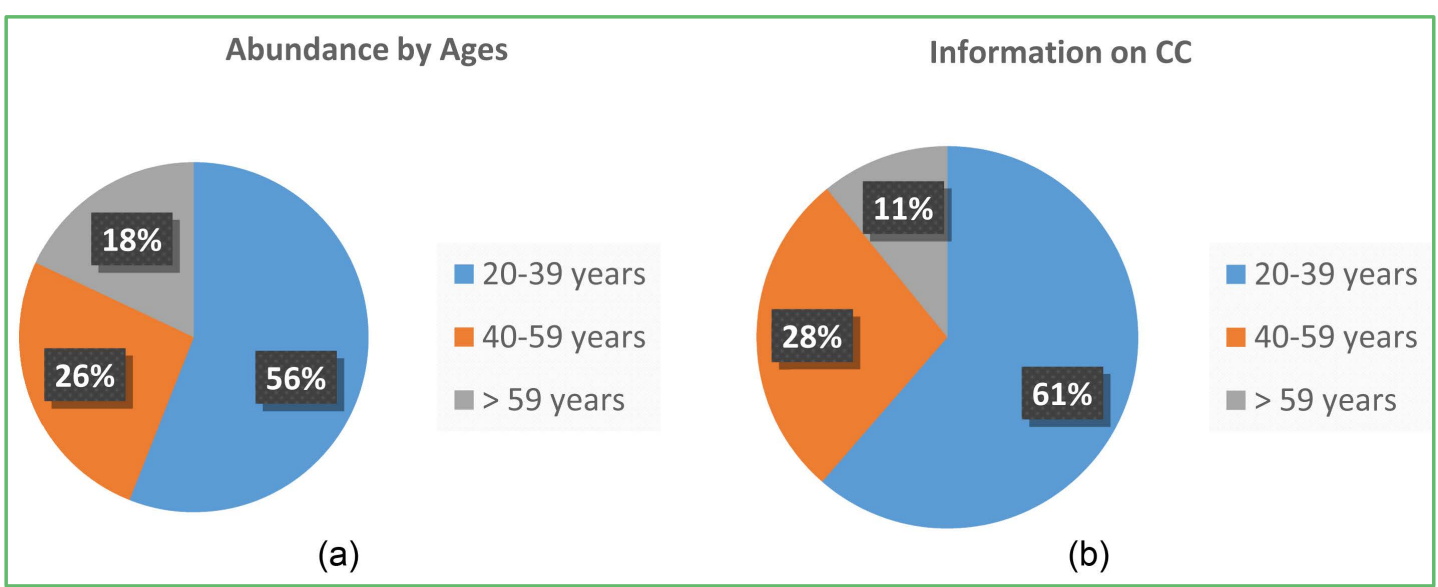

Figure 5. Distribution of interviewees’ ages (a) and Information on climate change (b).

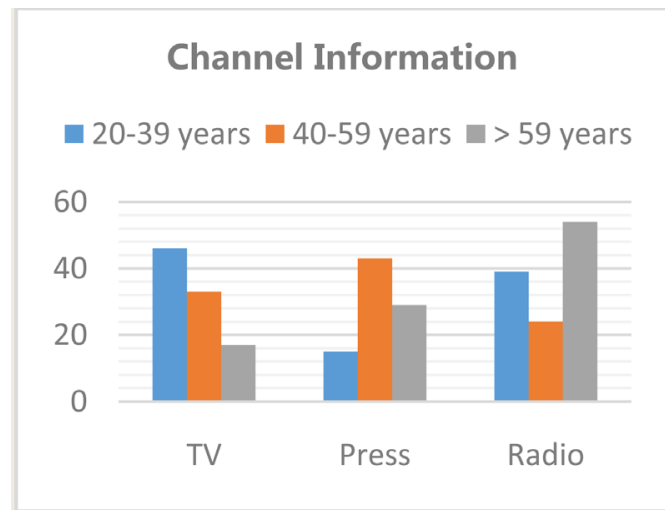

(a)

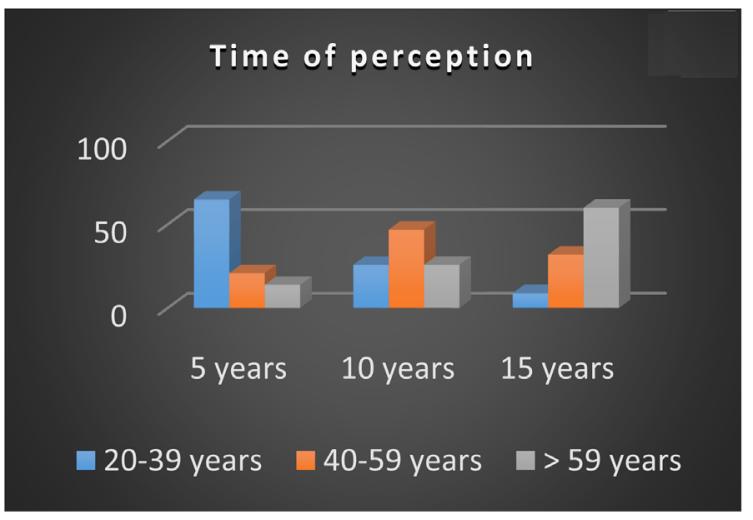

(b)

Figure 6. Channel information (a) and Time of perception (b) of climate change in mangrove areas.

\subsection{Local Endogenous Measures}

In the operations of adaptation, it is necessary to have permanently in mind relevant questions as what or who must adapt before thinking on efficient mechanisms of adaptation. It is therefore important to establish solid relationships with the major targets in order to elaborate a list of scientific assumptions likely to improve knowledge when they are linked especially to the functioning of other parameters of the natural systems. In addition to this, a measure of adaptation will be better when the populations in charge of its implementation understand and appreciate the paramount necessity.

In accordance with the past and present climatic risks usually observed in the locality, the populations have adopted various types of behaviors to fit one's surroundings. According to recorded events, the reactions achieved ranged from common panic to the abandonment of site. The relevant endogenous measures of adaptation from the survey and which can be used as a base of discussion in the determination of the potential options of adaptation are recorded in Table 1.

The impacts of climate change are anticipated to be greatest in low and lower-middle-income countries where most of the world's poor live [44]. In most of these countries, climate change is expected to worsen existing environmental and resource problems and generate new ones, thereby endangering livelihoods, intensifying conflicts over resources, and inducing greater migration within and across national boundaries [45]. Given the inevitability of climate change, a critical question is how societies can best adapt to it?

It is widely recognized that judicious measures of adaptation can reduce the vulnerability. However, it is only very recently that research is deeply interested in the capacity of the populations to react to the environmental constraints and the extreme climatic events. We noted that, the term local endogenous measures is analogous to 
Table 1. Local endogenous measures of adaptation to climate risks in the coastal region of Cameroon.

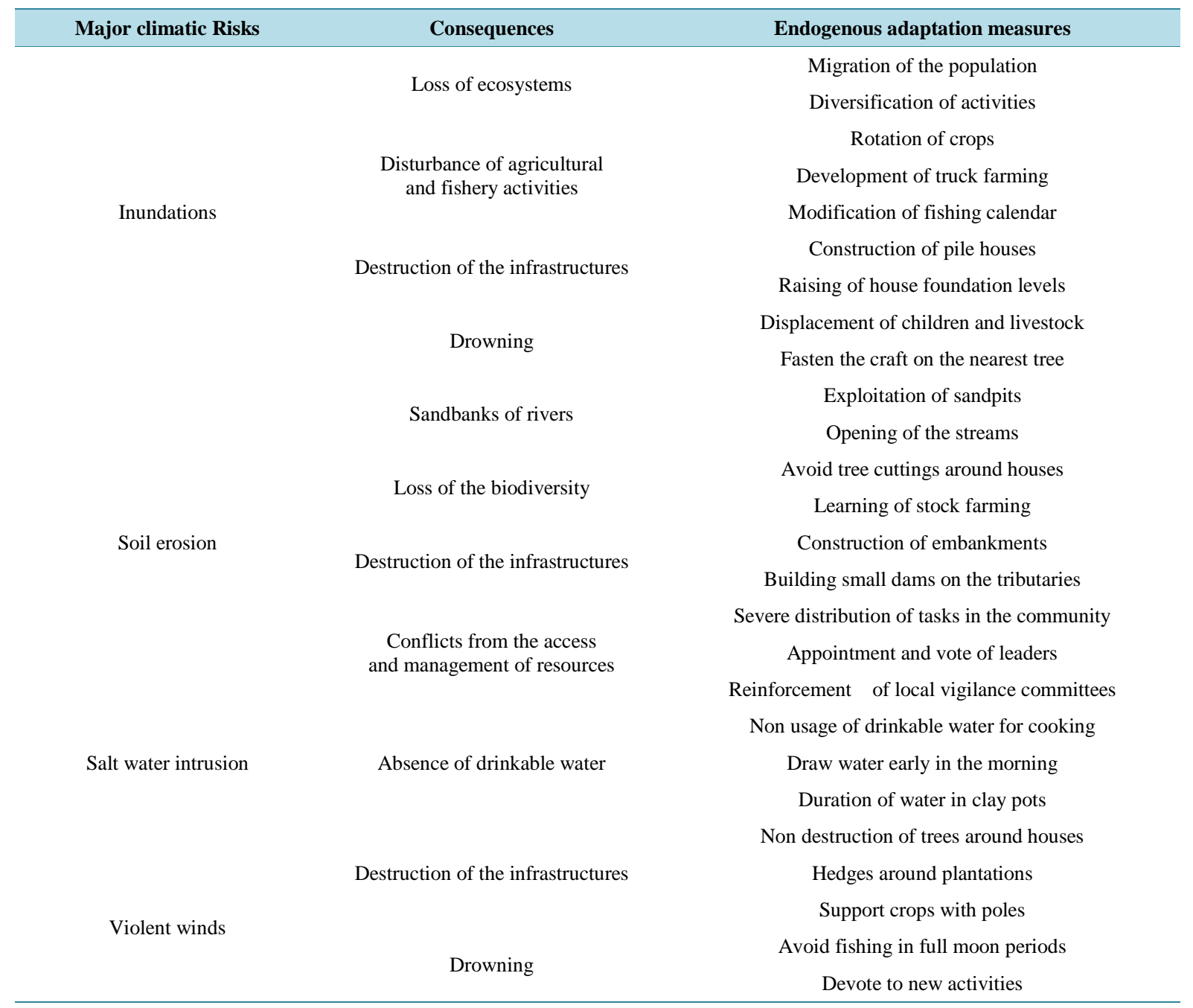

terms such as local and indigenous knowledge (LINK), local knowledge, traditional ecological knowledge, indigenous technical knowledge, endogenous knowledge [46] [47]. These measures can be categorized in four groups:

- perceptions and understandings of climatic changes and related natural phenomena (prediction of storms based on observations of the sky, sea and wind);

- livelihood sustainability practices (livelihood diversification);

- survival, coping and mitigation strategies (migration to higher ground, construction of houses using local materials);

- cultural belief systems (traditional rituals and ceremonies).

All these categories have been encountered in the investigation. The third group seems to be the most frequent situation which is normal in the context of poverty. On the other hand, the migrations found in this survey area must be considered as a temporary measure of adaptation since populations always tend to return to their land after the end of the manifestations from an extreme climatic event.

\section{Conclusion}

Perception on climate change and sea level rise is already felt by local populations except the appreciation on rainfall. Observations varied significantly by age and sex. The increase in frequency of floods and their impacts are the relevant indicators for populations to refuse predicted rainfall deficits in the area. Expected extension of 
the dry season could affect the natural regeneration and the structure of mangrove forests. No efficient and continuous endogenous measure of adaptation has been recorded. Considering the importance of woody species in the local economies, the urban demographic pressure, the lack of appropriate actions and adaptation measures will lead to the total degradation of mangrove ecosystems around cities. In Cameroon, mangroves are only found in the Atlantic front and tributaries. The various mechanisms of adaptation could produce best results when they are integrated into other policies such as the fight against natural disasters and regional planning. Adaptation measures will therefore play a basic role in the reduction of the width and the stretch from the real impacts and from the vulnerability of coastal zones to the climatic change.

\section{References}

[1] Santer, B.D., Taylor, K.E., Wigley, T.M.L., Johns, T.C., Jones, P.D., Karoly, D.J., Mitchell, G.F.B., Oort, A.H., Penner, J.E., Ramaswamy, V., Schwarzkopf, M.D., Stuffer, R.J. and Tett, S. (1996) A Search for Human Influences on the Thermal Structure of the Atmosphere. Nature, 382, 39-46. http://dx.doi.org/10.1038/382039a0

[2] Wigley, T.M.L., Smith, R.L. and Santer, B.D. (1998) Anthropogenic Influence on the Autocorrelation Structure of Hemispheric-Mean Temperature. Science, 282, 1676-1679. http://dx.doi.org/10.1126/science.282.5394.1676

[3] IPCC (2013) The Physical Science Basis. Intergovernmental Panel on Climate Change. Cambridge University Press, Cambridge.

[4] IPCC, Barros, V.R., Field, C.B., Dokken, D.J., Mastrandrea, M.D. and Mach, K.J. (2014) Climate Change 2014: Impacts, Adaptation, and Vulnerability. Part B: Regional Aspects. In: Mastrandrea, P.R. and White, L.L., Eds., Contribution of Working Group II to the Fifth Assessment Report of the Intergovernmental Panel on Climate Change, Cambridge University Press, Cambridge.

[5] UNEP (2008) Climate Change and Tourism Responding to Global Challenges. World Tourism Organization and the United Nations Environment Programme, Madrid.

[6] Massó I Alemán, S., Bourgeois, C., Appeltans, W., Vanhoorne, B., De Hauwere, N., Stoffelen, P., Heaghebaert, A. and Dahdouh-Guebas, F. (2010) The "Mangrove Reference Database and Herbarium”. Plant Ecology and Evolution, 143, 225-232. http://dx.doi.org/10.5091/plecevo.2010.439

[7] Giri, C., Ochieng, E., Tieszen, L.L., Zhu, Z., Singh, A., Loveland, T. and Duke, N. (2011) Status and Distribution of Mangrove Forests of the World Using Earth Observation Satellite Data. Global Ecology and Biogeography, 20, 154159. http://dx.doi.org/10.1111/j.1466-8238.2010.00584.x

[8] Din, N. and Baltzer, F. (2008) Richesse Floristique et Evolution des mangroves de l'Estuaire du Cameroun. African Geosciences Review, 2, 119-130.

[9] Spalding, M., Kainuma, M. and Collins, L. (2010) World Atlas of Mangroves. The International Society for Mangrove Ecosystems, Okinawa.

[10] Dahdouh-Guebas, F. and Koedam, N. (2008) Long-Term Retrospection on Mangrove Development Using Transdisciplinary Approaches: A Review. Aquatic Botany, 89, 80-92. http://dx.doi.org/10.1016/j.aquabot.2008.03.012

[11] Walters, B.B., Rönnbäck, P., Kovacs, J.M., Crona, B., Hussain, S.A., Badola, R., Primavera, J.H., Barbier, E. and Dahdouh-Guebas, F. (2008) Ethnobiology, Socio-Economics and Management of Mangrove Forests: A Review. Aquatic Botany, 89, 220-236. http://dx.doi.org/10.1016/j.aquabot.2008.02.009

[12] Midgley, G.F. and Bond, W.J. (2015) Future of African Terrestrial Biodiversity and Ecosystems under Anthropogenic Climate Change. Nature Climate Change, 5, 823-829. http://dx.doi.org/10.1038/nclimate2753

[13] Alongi, D.M. (2002) Present State and Future of the World’s Mangrove Forests. Environment and Conservation, 29, 331-349. http://dx.doi.org/10.1017/S0376892902000231

[14] Nfotabong, A.A., Din, N. and Dahdouh-Guebas, F. (2013) Qualitative and Quantitative Characterization of Mangrove Vegetation Structure and Dynamics in a Peri-Urban Setting of Douala (Cameroon): An Approach Using Air-Borne Imagery. Estuarine Coasts, 36, 1181-1192. http://dx.doi.org/10.1007/s12237-013-9638-8

[15] Di Nitto, D., Dahdouh-Guebas, F., Kairo, J.G., Decleir, H. and Koedam, N. (2008) Digital Terrain Modelling to Investigate the Effects of Sea Level Rise on Mangrove Propagule Establishment. Marine Ecology Progress Series, 356, 175-188. http://dx.doi.org/10.3354/meps07228

[16] Gilman, E.L., Ellison, J.C., Duke, N.C. and Field, C. (2008) Threats to Mangroves from Climate Change and Adaptation Options: A Review. Aquatic Botany, 89, 237-250. http://dx.doi.org/10.1016/j.aquabot.2007.12.009

[17] Dahdouh-Guebas, F., Verneirt, M., Tack, J.F. and Koedam, N. (1997) Food Preferences of Neosarmatium meinerti de Man (Decapoda: Sesarminae) and Its Possible Effect on the Regeneration of Mangroves. Hydrobiologia, 347, 83-89. http://dx.doi.org/10.1023/A:1003015201186 
[18] Cannicci, S., Burrows, D., Fratini, S., Lee, S.Y., Smith III, T.J., Offenberg, J. and Dahdouh-Guebas, F. (2008) Faunal Impact on Vegetation Structure and Ecosystem Function in Mangrove Forests: A Review. Aquatic Botany, 89, 186-200. http://dx.doi.org/10.1016/j.aquabot.2008.01.009

[19] Valiela, I., Bowen, J.L. and York, J.K. (2001) Mangrove Forests: One of the World's Threatened Major Tropical Environments. BioScience, 51, 807-815. http://dx.doi.org/10.1641/0006-3568(2001)051[0807:MFOOTW]2.0.CO;2

[20] Hauff, R.D., Ewel, K.C. and Jack, J. (2006) Tracking Human Disturbance in Mangroves: Estimating Harvest Rates on a Micronesian Island. Wetlands Ecology and Management, 14, 95-105. http://dx.doi.org/10.1007/s11273-005-2567-y

[21] Duke, N.C., Meynecke, J.O., Dittmann, S., Ellison, A.M., Anger, K., Berger, U., Cannicci, S., Diele, K., Ewel, K.C., Field, C.D., Koedam, N., Lee, S.Y., Marchand, C., Nordhaus, I. and Dahdouh-Guebas, F. (2007) A World without Mangroves? Science, 317, 41-42. http://dx.doi.org/10.1126/science.317.5834.41b

[22] Din, N., Saenger, P., Priso, R.J., Dibong, D.S. and Blasco, F. (2008) Logging Activities in Mangrove Forests: A Case Study of Douala Cameroon. African Journal of Environmental Science and Technology, 2, 22-30.

[23] Mohamed, M.O.S., Neukermans, G., Kairo, J.G., Dahdouh-Guebas, F. and Koedam, N. (2009) Mangrove Forests in a Peri-Urban Setting: The Case of Mombasa (Kenya). Wetlands Ecology and Management, 17, 243-255. http://dx.doi.org/10.1007/s11273-008-9104-8

[24] Alongi, D.M. (2015) The Impact of Climate Change on Mangrove Forests. Current Climate Change Report, 1, 30-39. http://dx.doi.org/10.1007/s40641-015-0002-x

[25] Alongi, D.M. (2008) Mangrove Forests: Resilience, Protection from Tsunamis, and Responses to Global Climate Change. Estuarine, Coastal and Shelf Science, 76, 1-13. http://dx.doi.org/10.1016/j.ecss.2007.08.024

[26] Smith, K.R., Woodward, A., Campbell-Lendrum, D., Chadee, D.D., Honda, Y. and Liu, Q. (2014) Human Health: Impacts, Adaptation and Co-Benefits. In: Field, C.B., Barros, V.R., Dokken, D.J., Mac, K.J., Mastrandrea, M.D. and Bilir, T.E., Eds., Climate Change 2014: Impacts, Adaptation, and Vulnerability. Part A: Global and Sectoral Aspects. Contribution of Working Group II to the 5th Assessment Report of the Intergovernmental Panel on Climate Change, Cambridge University Press, Cambridge.

[27] Giresse, P., Megope-Foonde, J.P., Ngueutchoua, G., Aloisi, J.C., Kuete, M. and Monteillet, J. (1996) Carte sédimentologique du plateau continental du Cameroun à1:200000. ORSTOM, Paris.

[28] Ngo-Massou, V.M., Essomè-Koum, G.L., Ngollo-Dina, E. and Din, N. (2012) Composition of Macrobenthos in the Wouri River Estuary Mangrove, Douala, Cameroon. African Journal of Marine Science, 34, 349-360. http://dx.doi.org/10.2989/1814232X.2012.725288

[29] Ngo-Massou, V.M., Essomè-Koum, G.L., Kotte, M.E. and Din, N. (2014) Biology and Distribution of Mangrove Crabs in the Wouri River Estuary, Douala, Cameroon. Journal of Water Resource and Protection, 6, 236-248. http://dx.doi.org/10.4236/jwarp.2014.64029

[30] Faraco, L.F.D., Andriguetto-Filho, J.M. and Lana, P.C. (2010) A Methodology for Assessing the Vulnerability of Mangroves and Fisherfolk to Climate Change. Pan-American Journal of Aquatic Sciences, 5, 33-51.

[31] Din, N., Ngo-Massou, V.M., Kotte-Mapoko, E., Essoh-Mongo, M.C. and Essomè-Koum, G.L. (2014) Evolution of Mangrove Crabs Distribution in the Atlantic Coast of Cameroon. In: Ardovi, C., Ed., Crabs, Global Diversity, Behavior and Environmental Threats, Nova Publishers, New York.

[32] Tittensor, D.P., Mora, C., Jetz, W., Lotze, H.K., Ricard, D. and Vanden Berghe, E. (2010) Global Patterns and Predictors of Marine Biodiversity across Taxa. Nature, 466, 1098-1101. http://dx.doi.org/10.1038/nature09329

[33] Wang, X., Piao, S., Ciais, P., Friedlingstein, P., Myneni, R.B. and Cox, P. (2014) A Two-Fold Increase of Carbon Cycle Sensitivity to Tropical Temperature Variations. Nature, 506, 212-215. http://dx.doi.org/10.1038/nature12915

[34] Le Quéré, C., Raupach, M.R., Canadell, J.G. and Marland, G. (2009) Trends in the Sources and Sinks of Carbon Dioxide. Nature Geoscience, 2, 831-836. http://dx.doi.org/10.1038/ngeo689

[35] Menéndez, M. and Woodworth, P.L. (2010) Changes in Extreme High Water Levels Based on a Quasi-Global TideGauge Data Set. Journal of Geophysical Research, 115, 100-111. http://dx.doi.org/10.1029/2009JC005997

[36] Duarte, C.M., Losada, I.J., Hendriks, I.E., Mazarrasa, I. and Marbà, N. (2013) The Role of Coastal Plant Communities for Climate Change Mitigation and Adaptation. Nature Climate Change, 3, 961-968. http://dx.doi.org/10.1038/nclimate1970

[37] Phan, L.K., Van Thiel de Vries, J.S.M. and Stive, M.J.F. (2015) Coastal Mangrove Squeeze in the Mekong Delta. Journal of Coastal Research, 31, 233-343. http://dx.doi.org/10.2112/JCOASTRES-D-14-00049.1

[38] Ye, Y., Gu, Y.T., Gao, H.Y. and Lu, C.Y. (2010) Combined Effects of Simulated Tidal Sea-Level Rise and Salinity on Seedlings of a Mangrove Species, Kandelia candel (L.) Druce. Hydrobiologia, 641, 287-300. http://dx.doi.org/10.1007/s10750-010-0099-9

[39] Yáñez-Espinosa, L. and Flores, J. (2011) A Review of Sea-Level Rise Effect on Mangrove Forest Species: Anatomical 
and Morphological Modifications. In: Casalengo, S., Ed., Global Warming Impacts—Case Studies on the Economy, Human Health, and on Urban and Natural Environments, InTech, Rijeka, 253-276.

[40] Ellison, J.C. (1992) Mangrove Retreat with Rising Sea Level. Unpublished Ph.D. Dissertation, University of California, Berkeley.

[41] Syvitski, J.P.M., Kettner, A.J., Overeem, I., Hutton, E.W.H. and Hannon, M.T. (2009) Sinking Deltas Due to Human Activities. Nature Geosciences, 2, 681-686. http://dx.doi.org/10.1038/ngeo629

[42] Erban, L.E., Gorelick, S.M. and Zebker, H.A. (2014) Groundwater Extraction, Land Subsidence and Sea Level Rise in the Mekong Delta, Vietnam. Environmental Research Letters, 9, 084010. http://dx.doi.org/10.1088/1748-9326/9/8/084010

[43] Keita, E.A. (1990) Courantologie et quelques paramètres phésiques dans l'estuaire de la Bimbia, Cameroun. Rapport technique COMARAF sur l'étude pluridisciplinaire de l'écosystème de l'estuaire de la Bimbia, Limbe.

[44] Parry, M.L., Canziani, J.P., Palutikof, J.P., Van der Linden, P.J. and Hanson, C.E. (2007) Change 2007: Impacts, Adaptation and Vulnerability. Contribution of Working Group II to the 4th Assessment Report of the Intergovernmental Panel on Climate Change. Cambridge University Press, Cambridge.

[45] McLeman, R. and Smit, B. (2006) Migration as an Adaptation to Climate Change. Climatic Change, 76, 31-53. http://dx.doi.org/10.1007/s10584-005-9000-7

[46] Fishman, R. (2012) Climate Change, Rainfall Variability, and Adaptation through Irrigation: Evidence from Indian Agriculture. Working Paper, Columbia University, New York.

[47] Smith, S.C. and Malik, A.S. (2012) Adaptation to Climate Change in Low-Income Countries: Lessons from Current Research and Needs from Future Research. Institute for International Economic Policy Working Paper Series, the George Washington University, Washington DC. 